\title{
A Study of Monoamine Metabolism in Human Epilepsy
}

\author{
D. Louw, G.R. Sutherland, G.B. Glavin and J. Girvin
}

\begin{abstract}
Fourteen patients with intractable epilepsy underwent surgical resection of their epileptogenic focus. Hippocampal and temporal cortical samples were obtained, and subjected to high performance liquid chromatography with electrochemical detection. Levels of 5-hydroxyindoleacetic acid (5-HIAA) in actively spiking temporal cortex were $0.454 \pm 0.012 \mathrm{ng} / \mathrm{mg}$ (mean $\pm \mathrm{SEM}$ ), contrasting with less actively spiking cortex values of $0.248 \pm 0.042 \mathrm{ng} / \mathrm{mg}$ and normal literature values, obtained from post-mortem material, of $0.140 \pm 0.050 \mathrm{ng} / \mathrm{mg}$. Similarly, homovanillic acid (NVA) levels were significantly increased in epileptic tissue compared to normal literature values. Actively spiking cortex values were $0.172 \pm 0.001 \mathrm{pg} / \mathrm{mg}$, less active cortex values were $0.058 \pm 0.012 \mathrm{pg} / \mathrm{mg}$, and literature values were $0.011 \pm 0.002 \mathrm{pg} / \mathrm{mg}$. Although a direct statistical comparison between the data reported here and literature values may not be valid, the findings show a continuum from normal through increasingly active electrode sites, likely reflecting a true biologic phenomena. Similarly, statistically significant increases in 5-HIAA and HVA levels were found in hippocampal tissue, which also showed significantly lower dihydroxyphenylacetic acid levels. We conclude that raised levels of serotonin and dopamine metabolites in actively spiking cortex likely reflect an increase in their turnover, and are an epileptic epiphenomenon. Exaggeration of turnover may represent the "metabolic noise" of epilepsy, rather than a concerted strategy of local or distal neurons to contain an epileptogenic focus.
\end{abstract}

RÉSUMÉ: Étude du métabolisme des mono-amines dans l'épilepsie chez l'humain Quatorze patients souffrant d'épilepsie résistante au traitement ont subi une résection chirurgicale de leur foyer épileptique. Des échantillons de tissus prélevés au niveau de l'hippocampe et du cortex temporal ont été soumis à une chromatographie en phase liquide à haute performance avec détection électrochimique. Les niveaux d'acide 5-hydroxy-indole acétique (S-HIAA) dans le cortex temporal qui était le site d'une activité électro-encéphalographique importante de type pointe étaient de $0.454 \pm 0.012 \mathrm{ng} / \mathrm{mg}$ (moyenne de \pm SEM), en regard de $0.248 \pm 0.042 \mathrm{ng} / \mathrm{mg}$ dans le cortex dont l'activité de type pointe était moindre et de $0.140 \pm 0.050 \mathrm{ng} / \mathrm{mg}$, correspondant à des valeurs normales selon la littérature, dans du matériel provenant d'autopsies. Les taux d'acide homovanilique (HVA) étaient également élevés de façon significative dans le tissu provenant de patients épileptiques comparés aux taux normaux cités dans la littérature. Les taux du cortex dont l'activité de type pointe était importante étaient de $0.172 \pm 0.001 \mathrm{pg} / \mathrm{mg}$, ceux de zones moins actives étaient de $0.058 \pm 0.012 \mathrm{pg} / \mathrm{mg}$, alors que les taux cités dans la littérature sont de $0.011 \pm 0.002 \mathrm{pg} / \mathrm{mg}$. Même si une comparaison statistique directe entre les données rapportées ici et celles de la littérature n'est peut-être pas valide, ces observations montrent qu'il existe un continuum allant de valeurs normales à des valeurs s'élevant progressivement avec l'activité des sites étudiés, reflétant probablement un phénomène biologique réel. De même, des niveaux de S-HIAA et de HVA augmentés de façon significative ont été observés dans le tissu de l'hippocampe ainsi que des taux significativement plus bas d'acide dihydroxy-phényl acétique. Nous concluons que des taux élevés de métabolites de la sérotonine et de la dopamine dans le cortex ayant une activité importante de type pointe reflètent une augmentation de leur turn-over et sont un épiphénomène épileptique. Une exagération du turn-over peut représenter le "bruit métabolique" de l'épilepsie, plutôt qu'une stratégie concertée des neurones locaux ou distaux destinée à contenir un foyer épileptogéne.

Can. J. Neurol. Sci. 1989; 16:394-397

Physiologic actions of serotonin are diverse and poorly understood, but a large body of information has accumulated implicating an inhibitory role in seizure models. ${ }^{1-3}$ Increased seizure susceptibility after reserpine pre-treatment and subsequent depletion of serotonin has been demonstrated in man. 4,5 Studies of cerebrospinal fluid (CSF) in various epileptic populations have suggested both an increase ${ }^{6}$ and decrease ${ }^{7}$ in turnover of serotonin. Serotonin levels obtained from surgical specimens were too scattered to suggest a trend. ${ }^{7}$
Dopamine pathways are more discrete, and experimental evidence for seizure attenuation is conflicting. ${ }^{1,8,9}$ Homovanillic acid (HVA), a major dopamine metabolite, has been shown to be both increased and decreased in the CSF of epileptic individuals. Both decreased and increased dopamine levels have been described in surgically resected epileptic cortex in humans. 7,9

Experimental designs of animal seizure models, however, may be criticized. Drugs that have been tested do not limit their action to single neurotransmitter systems. 10 Specific brain

From the Departments of Pharmacology and Surgery (Neurosurgery), The University of Manitoba, Health Sciences Centre, Winnipeg (D.L., G.R.S., G.B.G.) and the Department of Neurosciences, University of Western Ontario, University Hospital, London, Ontario (J.G.)

Received March 1, 1989. Accepted in final form August 28, 1989

Reprint requests to: Garnette Sutherland, M.D., Departments of Pharmacology and Surgery (Neurosurgery), 61 Emily Street, Winnipeg, Manitoba, Canada R3E IY9 
Table 1: Clinico-Pathological Features of 14 Patients with Intractable Temporal Lobe Epilepsy

\begin{tabular}{|c|c|c|c|c|}
\hline Patient & Sex & $\begin{array}{c}\text { Age } \\
\text { (Years) }\end{array}$ & $\begin{array}{c}\text { Seizure Duration } \\
\text { (Years) }\end{array}$ & Pathology \\
\hline 1 & $\mathbf{M}$ & 29 & 18 & $\begin{array}{l}\text { gliosis, mild cortical dys- } \\
\text { plasia, dendritic spine } \\
\text { aberrations (Golgi stain) }\end{array}$ \\
\hline 2 & $\mathrm{~F}$ & 26 & 5 & same as patient 1 \\
\hline 3 & $\mathrm{~F}$ & 25 & 24 & same as patient 1 \\
\hline 4 & $\mathrm{~F}$ & 29 & 27 & $\begin{array}{l}\text { mild cortical dysplasia } \\
\text { dendritic spine aberra- } \\
\text { tions }\end{array}$ \\
\hline 5 & $\mathbf{M}$ & 22 & 16 & same as patient 4 \\
\hline 6 & $M$ & 33 & 3 & $\begin{array}{l}\text { gliosis, neuronal loss, } \\
\text { changes of acute ischemia }\end{array}$ \\
\hline 7 & M & 22 & 17 & $\begin{array}{l}\text { gliosis, moderate cortical } \\
\text { dysplasia }\end{array}$ \\
\hline 8 & $\mathbf{M}$ & 24 & 12 & $\begin{array}{l}\text { gliosis, dendritic spine } \\
\text { aberrations }\end{array}$ \\
\hline 9 & $M$ & 41 & 27 & hippocampal gliosis \\
\hline 10 & $\mathrm{~F}$ & 31 & 30 & $\begin{array}{l}\text { dendritic spine aberra- } \\
\text { tions }\end{array}$ \\
\hline 11 & $\mathbf{M}$ & 27 & 1 & low grade astrocytoma \\
\hline 12 & $\mathbf{M}$ & 34 & 0.3 & low grade astrocytoma \\
\hline 13 & $\mathrm{~F}$ & 40 & 1 & low grade astrocytoma \\
\hline 14 & $\mathbf{M}$ & 22 & 2 & $\begin{array}{l}\text { gliosis, dendritic spine } \\
\text { aberrations, arteriovenous } \\
\text { malformation mid tempo- } \\
\text { ral lobe }\end{array}$ \\
\hline
\end{tabular}

lesions may stimulate compensatory changes in other brain regions. 10

In view of the inherent flaws of much experimental work, and the conflicting data derived, we undertook to measure monoamine metabolism in human epilepsy cortex.

\section{Clinical Methods and Materials}

\section{Patient Population}

Tissue samples were obtained from fourteen patients with intractable temporal lobe epilepsy (Table 1). The majority of patients (8) were male. Their mean age \pm SEM was $27 \pm 3$ years and the mean duration of symptoms $13 \pm 3$ years. Multiple antiepileptic drugs were administered chronically and in a variety of combinations. In addition to neurochemical analysis, all temporal lobe anterior hippocampal specimens were histologically examined. In patients with underlying neoplasms, the tissue samples were obtained from cortex remote from the tumor and free of cellular infiltration.

\section{Tissue Samples}

All surgical procedures were performed under local anesthesia. Following completion of the intraoperative electrocorticogram (ECoG), tissue samples were rapidly obtained from the principal spike focus (most actively spiking gyrus) and anteriorly situated gyri (less actively spiking cortex). Samples (0.3-1.5g, predominantly gray matter) were obtained prior to coagulation, and were immediately placed in liquid nitrogen and stored at $80^{\circ} \mathrm{C}$ until analysis. All tissue $(15-151 \mathrm{mg} / \mathrm{sample}$; mean $=$ $63.2, \mathrm{mg} \pm 9.6 \mathrm{mg}$ ) was analyzed by high pressure liquid chromatography (HPLC) with electrochemical detection. The col- umn was a $4.6 \mathrm{~mm} \times 15.0 \mathrm{~cm}$ Ultrasphere ODS $5 \mu \mathrm{m}$ in the reverse phase, protected by a Beckman Guard-Pak pre-column. An ESA Coulochem Model 5100A electrochemical detector with dual graphite electrodes, protected by model 5011 guard cell with detector potential maintained at $+0.80 \mathrm{v}$ or less versus a $\mathrm{Ag} / \mathrm{AgCl}$ reference electrode, was used. The mobile phase consisted of $75 \mu \mathrm{M}$ sodium phosphate, $1.0 \mathrm{mM}$ octyl sodium sulfate, $50 \mu \mathrm{M}$ EDTA and acetonitrile: water (90:10), with $\mathrm{pH}$ adjusted to 2.90 with phosphoric acid, according to the method of Warnhoff."1 Tissues were weighed, homogenized (Brinkmann Polytron, setting 6 to $10 \mathrm{sec}$ ) in $800 \mu \mathrm{L}$ of the mobile phase and centrifuged at $4^{\circ} \mathrm{C}$ for $15 \mathrm{~min}$ at $25,000 \times \mathrm{g}$. The supernatants were filtered through $0.22 \mu \mathrm{m}$ filters (Millipore GVWP 01300) and $25 \mu \mathrm{L}$ aliquots of the filtrate injected onto the column. Standards, comprised of 1 -noradrenaline bitartrate, dopamine, 5-hydroxytryptamine, 5-hydroxyindoleacetic acid homovanillic acid, dihydroxyphenylacetic acid (Sigma) and 3-methoxy-4hydroxyphenylethylerieglycol sulfate, potassium salt (Calbiochem), were included in each run. Data were quantified by peak-to-peak integration of the area under the curve with a Shimadzu CR3A integrator and are expressed as nanograms or picograms per mg wet tissue weight.

All data are presented as a mean \pm SEM and analyzed by Student's t-test, comparing epileptic to normal values with Type 1 error probability controlled by Dunn's procedure. Values for monoamine metabolite levels in non-diseased, normal human brain are taken from Mackay et al (1978). ${ }^{12}$ In this study, the stability of post-mortem samples was not affected by room temperature exposure prior to freezing. In addition, other investigators have also shown that up to 72 hours of room temperature exposure of human brain tissue permits accurate determination of monoamines. ${ }^{13}$ Our samples were frozen within $1 \mathrm{~min}$. of removal from the patients.

\section{Results}

Table 1 displays histopathologic data. The vast majority of patients demonstrated varied combinations of gliosis, cortical dysplasia and dendritic spine aberrations (Golgi stains). Previously suspected, low-grade astrocytoma was diagnosed in three cases. A single case of a small mid temporal lobe arteriovenous malformation was noted. Pathologic features and duration of epilepsy did not significantly alter monoamine neurochemical data.

Table 2 summarizes the monoamine metabolite levels in temporal cortical tissue. Both actively spiking and less actively spiking temporal cortical tissue exhibited significantly higher 5-

Table 2: 5-HIAA, HVA, and DOPAC Levels of Temporal Cortex $(n=14)$ Resected From Epileptic Patients (Mean \pm SEM)

\begin{tabular}{lccc}
\hline \hline Tissue & 5-HIAA $(\mathrm{ng} / \mathrm{mg})$ & NVA $(\mathrm{pg} / \mathrm{mg})$ & DOPAC $(\mathrm{pg} / \mathrm{mg})$ \\
\hline $\begin{array}{l}\text { Normal temporal } \\
\text { cortex }\end{array}$ & $0.140 \pm 0.050$ & $0.011 \pm 0.002$ & $0.033 \pm 0.003$ \\
$\begin{array}{l}\text { Actively spiking } \\
\text { cortex }\end{array}$ & $0.454 \pm 0.012^{*}$ & $0.172 \pm 0.001^{*}$ & $0.005 \pm 0.002^{* *}$ \\
$\begin{array}{l}\text { Less actively } \\
\text { spiking cortex }\end{array}$ & $0.248 \pm 0.042^{*}$ & $0.058 \pm 0.012^{*}$ & $0.008 \pm 0.001^{* *}$ \\
\hline
\end{tabular}

* significantly greater than normal value, $\mathrm{p}<0.001$

** significantly less than normal value, $p<0.05$

+ Data from reference $12(n=10)$ 
Table 3: 5-HIAA, HVA, and DOPAC Levels in Hippocampus $(n=5)$ Resected from Epileptic Patients (Mean \pm SEM)

\begin{tabular}{lccc}
\hline \hline Tissue & 5-HIAA (ng/mg) & HVA $(\mathrm{pg} / \mathrm{mg})$ & DOPAC $(\mathrm{pg} / \mathrm{mg})$ \\
\hline $\begin{array}{l}\text { Normal } \\
\text { Hippocampus }\end{array}$ & $0.079 \pm 0.022$ & $0.009 \pm 0.001$ & $0.037 \pm 0.003$ \\
$\begin{array}{l}\text { Actively spiking } \\
\text { Hippocampus }\end{array}$ & $0.369 \pm 0.021^{*}$ & $0.135 \pm 0.001^{*}$ & $0.013 \pm 0.002^{* *}$ \\
\hline
\end{tabular}

* significantly greater than normal value, $\mathrm{p}<0.05$

** significantly less than normal value, $\mathrm{p}<0.05$

+ Data from reference $12(n=10)$

hydroxyindoleacetic acid (5-HIAA) and HVA levels compared to normal brain values. Actively spiking sites showed a $325 \%$ increase in 5-HIAA relative to control levels, while less active sites showed a $177 \%$ increase. On the other hand, these tissues had significantly less dihydroxyphenylacetic acid (DOPAC) levels than observed in normal human temporal cortex. All other amines and metabolites were undetectable.

Table 3 summarizes the analysis of hippocampal tissue $(\mathrm{n}=5)$. 5-HIAA and HVA levels were again significantly higher than normal brain values ( $467 \%$ and $1500 \%$ respectively), while DOPAC levels were significantly lower than those seen in normal brain.

It must be noted that we are comparing our present data with minimal room temperature exposure and analysis by HPLC, to those obtained by Mackay, 12 in which the tissue was exposed to room temperature for a longer time period and which were analyzed fluorometrically. Although a direct statistical comparison may not be valid, the data shows a trend from normal, 12 to less active sites to the most active sites. That such a continuum exists, suggests that the comparisons are valid and likely reflect a true biological phenomena.

\section{Discussion}

The results clearly indicate that statistically significant differences in monoamine metabolism distinguish spiking from nonspiking cortex. The data were obtained from human temporal and hippocampal cortex, and specifically demonstrate augmentation of serotonin and dopamine turnover in spiking regions. These data are further supported by those of Goldstein et al ${ }^{9}$ who also found evidence for increased catecholaminergic activity in human epileptic foci. This discussion will attempt to define possible mechanisms underlying this phenomenon.

Multiple factors have been implicated in the regulation of catecholamine release. ${ }^{14}$ The local synaptic concentration of catecholamines controls their own release through effecting the presynaptic autoreceptors. ${ }^{15}$ Prostaglandins, vaso-active amines, polypeptides such as angiotension II and acetylcholine are all considered to regulate catecholamine release. ${ }^{14}$ It is apparent that the local metabolic milieu may exert a powerful influence on catecholamine turnover in spiking cortex. This molecular microenvironment will be significantly different in an epileptic focus, and we propose to call its effect on catecholamine turnover the metabolic "noise" of the focus.

Neuronal discharges occurring in seizures cause catecholamine release which would, in turn, stimulate re-uptake and synthesis thereby increasing their turnover rate and levels of metabolites measured. ${ }^{10}$ Ferrendelli suggested that seizure discharges cause a release from intracellular stores of biogenic amines and adenosine, and that these substances then act at synaptic sites to increase intracellular cyclic AMP levels. 10 The cyclic AMP may, in turn, alter membrane ion permeability, especially that of calcium.

A small number of excitatory neurons may subjugate a larger brain region by stimulation of inhibitory neurons that are synaptically connected to that region. ${ }^{16}$ Lesion experiments suggest the plausibility of such a concept. ${ }^{17}$ Furthermore, positron emission tomographic studies have demonstrated the existence of interictal hypometabolism in the entire temporal lobe, implying an inhibitory influence from distal neuronal projections. ${ }^{16}$ It is known that increased impulse flow results in an increase in the turnover of monoamine transmitters. 18 This recruitment of inhibitory projections in an effort to contain epileptic foci may occur in the serotonergic system, which has diffuse cortical projections. ${ }^{19}$ Dopamine, however, is largely restricted in its distribution to frontal and cingulate areas. 19

Speculation on the significance of monoamine metabolism in epilepsy must be guarded if it is based purely on measurements of turnover. Concomitant measurement of enzyme and receptor activity would complement the assessment of turnover. An increase in tyrosine hydroxylase activity in the epileptic focus has been reported, as well as a reduction in the number of alpha 1 -adrenoreceptors. ${ }^{20}$ In addition, the re-uptake of catecholamines and serotonin is, in part, dependent upon normally functioning glia. ${ }^{21}$ The majority of primary catecholamine metabolites may be further metabolized, and drugs or different physiological conditions may affect routes of metabolism and their rate of removal from the central nervous system. ${ }^{22}$ This may occur independently of any influence on amine turnover. Moreover, many of the factors involved in the determination of steady state concentrations of these metabolites remain to be elucidated. ${ }^{22}$

Although there is strong evidence categorizing an inhibitory role for serotonin in epilepsy, the argument is not as convincing for dopamine. It is premature to contemplate a specifically defined anticonvulsant role for either transmitter, recognizing the nebulous nature of our current conceptions of epileptogenic mechanisms. In addition, catecholamine and indoleamine synaptic organization are similar, resulting in a considerable overlap in their pharmacology. ${ }^{20,22}$ Catecholamines have diverse effects on the metabolism of amino-acids, cyclic nucleotides and other neurotransmitters and hence may indirectly, as well as directly, influence neuronal activity. It is also thought that multiple endogenous anticonvulsant substances exist. ${ }^{23}$ Opiate peptides, prostaglandins, thyrotropin-releasing hormone, adenosine, inosine and benzodiazepines may be involved.

Given the dynamic and diverse nature of biochemical and physiological events that constitute the epileptic focus, allied with limited data, it is concluded that the results of this study reflect the metabolic "noise" of the epileptic focus.

\section{ACKNOWLEDGEMENTS}

This work has been funded through the Medical Research Council of Canada. Appreciation is extended to Dr. Neelan Pillay for his assistance in patient selection, Kathleen Kiernan-Burns for her technical expertise, and to Emi Okamoto for typing the manuscript. 


\section{REFERENCES}

1. Wenger GR, Stitzel RE, Craig CR. The role of biogenic amines in the reserpine-induced alteration of minimal electroshock seizure thresholds in the mouse. Neuropharmacol 1973; 12: 693-703.

2. Lazarova M, Bendotti C, Samanin R. Studies on the role of serotonin in different regions of the rat central nervous system on pentylenetetrazol-induced seizures and the effect of Di-n-propylacetate. Arch Pharmacol 1983; 322: 147-152.

3. Sparks DL, Buckholtz. Combined inhibition of serotonin uptake and oxidative deamination attenuates audiogenic seizures in DBA/2J mice. Pharmacol Biochem Behav 1985; 23: 753-757.

4. Pallister PD. Aggravation of epilepsy by reserpine, associated with possible bleeding and clotting disturbances. Rocky Mt Med J 1982; 56: 45-50.

5. Maynert E, Marczynski T, Browning $R$. The role of neurotransmitters in the epilepsies. Adv Neurol 1975; 13: 79-147.

6. Leino E, MacDonald E, Araksinen M, et al. Homovanillic acid and 5-hydroxyindoleacetic acid levels in cerebrospinal fluid of patients with progressive myoclonus epilepsy. Acta Neurol Scand 1980; 62: 41-54.

7. Mori A, Hiramatsu M, Namba S, et al. Decreased dopamine level in the epileptic focus. Res Com Chem Pathol Pharmacol 1987; 56: 157-164.

8. Deschaepdryver A, Piette Y, Delaunois A. Brain amines and electroshock threshold. Arch Int Pharmcodyn Ther 1962; 140; 358367.

9. Goldstein DS, Nadi NS, Stull R, et al. Levels of catechols in epileptogenic and nonepileptogenic regions of the human brain. $J$ Neurochem 1988; 50: 225-229.

10. Ferrendelli JA. Roles of biogenic amines and cyclic nucleotides in seizure mechanisms. Ann Neurol 1984; 16: 598-603.

11. Warnhoff M. Simultaneous determination of norepinephrine, dopamine, 5-hydroxy-tryptamine and their metabolites in rat brain using high performance liquid chromatography with electrochemical detection. J Chromatog 1984; 307: 207-281.

12. Mackay AVP, Yates CM, Wright A, et al. Regional distribution of monoamines and their metabolites in the human brain. J Neurochem 1978; 30: 841-848.

13. Crow T. The biology of schizophrenia. Experimentia 1982; 38 1275-1282.

14. Langer S. Presynaptic regulation of the release of catecholamines. Pharmacol Rev 1980; 32: 337-362.

15. Roth RH. CNS dopamine autoreceptors: distribution, pharmacology and function. Ann NY Acad Sci 1984; 430: 27-53.

16. Engel J, Kuhl DE, Phelps ME, et al. Local cerebral metabolism during partial seizures. Neurol 1983; 33:400-413.

17. Hoffer B, Siggins G, Oliver A, et al. Activation of the pathway from locus coeruleus to rat cerebellar Purkinje neurons: pharmacological evidence of noradrenergic central inhibition. J Pharmacol Exp Ther 1973; 184: 553-569.

18. Salzman PM, Roth RH. Role of impulse flow in the short-term regulation of norepinephrine biosynthesis. Prog Neuro-biol 1979; 13: $1-60$.

19. Jones EG. Neurotransmitters in the cerebral cortex. J Neurosurg 1986; 65: 135-153.

20. Sherwin A. Amino-acid and catecholamine markers of metabolic abnormalities in human focal epilepsy. In: Delgado-Escueta, Ward AA Jr, Woodbury EM, Porter RJ, eds. Advances in Neurology. Raven Press, New York, 1986, 1011-1032.

21. Hertz L. Functional interactions between neurons and astrocytes. $I$. Turnover and metabolism of putative amino acid transmitters. Prog Neurobiol 1979; 13: 277-323.

22. Kopin I. Catecholamine metabolism: basic aspects and clinical significance. Pharmacol Rev 1985; 37: 333-364.

23. Dragunow M. Endogenous anticonvulsant substances. Neurosci Biobehav Rev 1986; 10: 229-244. 